\title{
The genus Agelaia Lepeletier (Hymenoptera, Vespidae, Polistinae) in Rio Grande do Sul, Brazil
}

\author{
Marcel Gustavo Hermes ${ }^{1} \&$ Andreas Köhler ${ }^{1}$
}

${ }^{1}$ Laboratório de Entomologia, Departamento de Biologia, Universidade de Santa Cruz do Sul. Av. Independência 2293, 96815-900 Santa Cruz do Sul-RS, Brazil. E-mail: andreas@unisc.br

\begin{abstract}
Resumo. O gênero Agelaia Lepeletier (Hymenoptera, Vespidae, Polistinae) no Rio Grande do Sul, Brasil. Agelaia Lepeletier, 1836 pertence ao grupo de vespas enxemeadoras de Polistinae, com espécies que se distribuem desde o México até o norte da Argentina. No Brasil, são encontradas 15 das 31 espécies descritas. Quatro espécies ocorrem no Rio Grande do Sul, duas das quais aqui registradas pela primeira vez para este Estado. Estas espécies são redescritas e uma chave para sua identificação é fornecida.
\end{abstract}

Palavras-Chave. Agelaia; novos registros; redescrições; Rio Grande do Sul.

Abstract. The genus Agelaia Lepeletier 1836 belongs to the swarming genera of the Polistinae, with species distributed from Mexico to northern Argentina. Fifteen of the 31 described species are found in Brazil. Four species occur in the State of Rio Grande do Sul, two of them recorded herein for the first time. Redescriptions and a key to these species are provided.

Keywords. Agelaia; new records; redescriptions; Rio Grande do Sul.

The genus Agelaia Lepeletier, 1836 belongs to the subfamily Polistinae and to the tribe Epiponini, which contains only social species. It is represented by 31 described species, distributed from Mexico to northern Argentina (COOPER 2001). Fifteen species are recorded from Brazil, and none of them is endemic. From Rio Grande do Sul state, however, just two Agelaia species are recorded: Agelaia multipicta Haliday, 1836 and Agelaia vicina de Saussure, 1854 (Carpenter, personal communication).

Agelaia, as other genera of the tribe Epiponini, is characterized by its swarming colony foundation (SILVEIRA \& CARPENTER 1995). Some species may achieve extremely large size colonies, such as Agelaia vicina reaching the largest colony among wasps and bees, with populations estimated up to one million adults (ZuCCHI et al. 1995; HunT et al. 2001).

The nest architecture diversity among Agelaia species is the greatest within Epiponini (HunT et al. 2001; JEANNE 1975; WenZEL 1998). Most of the species construct nests without an envelope, concealed in cavities of tree trunks. However, some species, as Agelaia timida Cooper, 2000 and A. baezae Richards, 1943 construct a true envelope (COOPER 2000).

The lack of works about social wasps in general has motivated the preparation of this article. Description of the species for Rio Grande do Sul state, including two new records, and a key to the species are provided. Moreover, the objective of this work also aims to encourage the entomologists of Rio Grande do Sul to intensify the collections, especially of social wasps, a very interesting and at the same time very complex group.

\section{MATERIALAND METHODS}

Collections of entomological material were made between September 2000 and December 2002, in the field sites of the following localities in Rio Grande do Sul: Porto Alegre, Santa Cruz do Sul, Encruzilhada do Sul, Rio Pardinho, Boa Vista, Vera Cruz, Derrubadas, Guaporé, São Francisco de Paula, Rio dos Índios and 15 de Novembro. The collectings were based on SAKAGAMI et al. (1967) methodology or through captures of wasps flying or landing on the vegetation.

The collected material was prepared and identified by the authors in the Laboratório de Entomologia of the Universidade de Santa Cruz do Sul, using the keys provided in CARPENTER \& MARques (2001), Richards (1978), GARCETE-BARRETt (1999) and COOPER $(2000,2001)$. The specimens are deposited in the entomological collection of the Departmento de Biologia CESC.

In addition, entomological material from other Rio Grande do Sul institutions was also examined. Abbreviations used: CESC, Coleção Entomológica da Universidade de Santa Cruz do Sul, Santa Cruz do Sul; MCNZ, Museu de Ciências Naturais, Fundação Zoobotânica do Rio Grande do Sul, Porto Alegre; MCTP, Museu de Ciência e Tecnologia, Laboratório de Pesquisas Biológicas, Pontifícia Universidade Católica do Rio 
Grande do Sul, Porto Alegre.

\section{RESULTS}

Key to the species of Agelaia (females) in Rio Grande do Sul state (adapted from RiCHARDS 1978 and GARCETE-BARRETT 1999)

1. Larger species (length of the fore wings about $16 \mathrm{~mm}$ ); body coloration brownish black; dorsal pronotal carinae lobate at sides (Fig. 1A)

A. angulata (Fabricius)

Smaller species (length of the fore wings less than 12 $\mathrm{mm}$ ); coloration variable; dorsal pronotal carinae not or slightly lobate at sides (Figs. 1B, 1C)

2(1). Transverse carina beneath fore wings projecting beyond base of Costa as a small point (Fig. 2B); clypeus entirely brown (yellow in males)

A. vicina de Saussure

Transverse carina at base of fore wings not projecting beyond Costa (Fig. 2A); clypeus entirely yellow or with black markings .....

3(2). Anterior pronotal carina not acute in front of fovea; legs and clypeus entirely yellow (Fig. 3A); terga I-II testaceous to brown, terga III-VI entirely black, sometimes with a thin yellow stripe posteriorly ........ A. pallipes (Olivier)

Anterior pronotal carina acute in front of fovea; clypeus, coxae and femora yellow with black markings (clypeus sometimes almost entirely black) (Fig. 3B); all terga black with a yellow stripe posteriorly ..... A. multipicta Haliday

\section{Agelaia multipicta Haliday, 1836}

Description. FWL 10.41-11.52 mm, mean $11.06(\mathrm{n}=10)$. Black with extensive yellowish maculation. Antennae entirely brownish black. Clypeus yellow with black markings (female clypeus sometimes almost entirely black). Head amost entirely yellow, except for black markings on gena, occiput, vertex and frons. Metanotum, scutellum, pronotum, pleuron and mesoscutum yellow marked, the last one with two yellow stripes. Propodeum with two broad yellow stripes. All terga brownish black with a yellow stripe posteriorly. Procoxa and mesocoxa yellow with brownish markings, metacoxa brown with yellowish markings. Profemur and mesofemur yellow with brownish markings, metafemur brown with yellowish markings. All tibiae and tarsi yellow. Wings hyaline with costal region of fore wings yellowish, venation brownish.

This is a widespread species, largely collected in Rio Grande do Sul state. The color variation was not observed among specimens collected in different regions. However, specimens collected in Paraguay appear to be slightly lighter on general coloration. Nests are built in cavities without an envelope.

Material examined. BRAZIL, Rio Grande do Sul: Boa Vista, 1 ㅇ (CESC 4183); Cambará do Sul, 8 , $1 \sigma^{\pi}$ (MCNZ 95510, 96645-96652); Campo Bom, 4 + (MCNZ 96203, 96217, 96271, 96277); Canela, 1 i (MCNZ 40935); Canguçu, 1 ㅇ (MCNZ 95182); Farroupilha, 5 \& (MCNZ 40550-40554); Gravataí, 3 + (MCNZ 40555-40557); Guaporé, 1 ㅇ

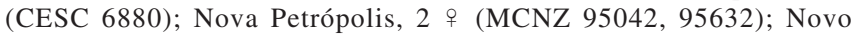
Hamburgo, 9 \& (MCNZ 40526, 40877, 65210, 65219, 96207, 96213, 96230, 96286, 96288); Porto Alegre, 2 ㅇ (MCNZ 40559, 95634); 15 de Novembro, 2 (CESC 1890, 7203); Rio dos Índios, 3 \%, (CESC 1887-1889); Rio Pardinho, 6 + (CESC 1885-1886, 7199-7202); Santa Cruz do Sul, 36 ㅇ (CESC 684, 753, 832, 960, 1079, 2460, 3248, 4174 4182, 4184-4200, 4287, 5157, 6190); São Francisco de Paula, 31 q (MCTP 1, 97-98, 103-105, 123-124, 192-196, 200, 204-209, 682, $765,2507,4955,5794,10655-10657,10857,11333,15126) ; 3$ 우 (CESC 7196-7198); São Jerônimo, 1 † (MCNZ 65023); São Leopoldo, 6 \& (MCNZ 65312-65314, 65344, 65351, 65357); Tenente Portela, 1 ㅇ (MCNZ 95487).

\section{Agelaia vicina de Saussure, 1854}

Description. FWL 8.31-10.66 mm, mean 9.66 ( $\mathrm{n}=10)$. Brown, with few or no yellowish markings. Clypeus entirely brown in females and entirely yellow in males. Sometimes with small yellow markings on head, pleuron, scutellum and metanotum. Sometimes tergum II with a yellow stripe posteriorly, which may be complete or not. All coxae and femora yellowish brown. All tibiae and tarsi yellow. Wings hyaline with costal region of fore wings yellowish, venation brownish.

Not as widespread as A. multipicta, but also largely collected in Rio Grande do Sul state. This species presents a color variation that seems not to be defined by its geographic distribution. We have examined specimens collected in the same field site, some with and some without yellow markings. Agelaia vicina usually build nests within shelters, but sometimes the nests are completely exposed, without an envelope.

Material examined. BRAZIL, Rio Grande do Sul: Boa Vista, 1 q (CESC 5466); Guaporé, 2 + (CESC 5331, 5332); Canela, 1 i (MCNZ 66436); Novo Hamburgo, $1 \sigma^{\pi}$ (MCNZ 96210); Rio dos Índios, 1 q (CESC 7192); Rio Pardinho, 1 + (CESC 7191); São Francisco de Paula, 33 ㅇ (MCTP 141, 2807, 4425, 4428, 4453, 4466, 4551, 4646, 6648, 6784, 6887, 6916, 7209, 7241, 7289, 7341, 7390, 7397, 7528, 7620,

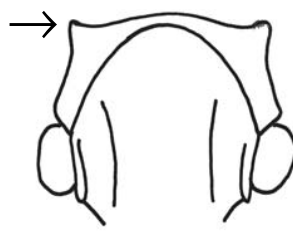

A

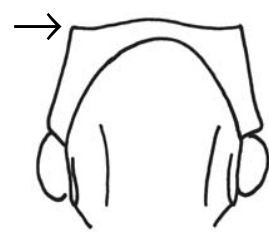

B

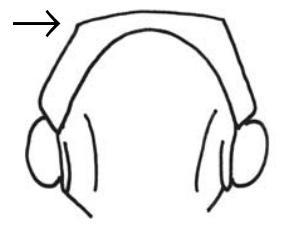

C
Fig. 1. Dorsal pronotal carinae: A, lobate at sides; B, slightly lobate at sides; C, not lobate. 


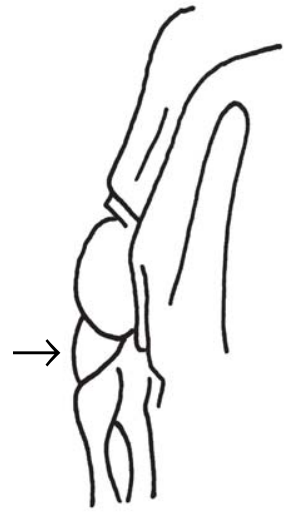

A

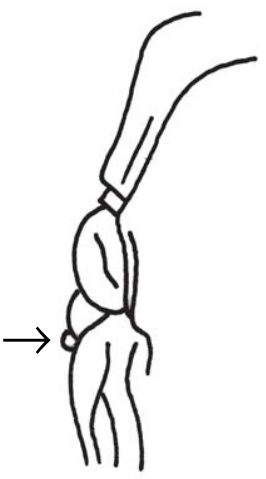

B
Fig. 2. Transverse carina at base of fore wings: A, not projecting beyond Costa; B, projecting forwards beyond base of Costa as a small point.

$7783,8014,8234,8816,8844,8845,9035,9045,9051,10654$, $12796,13849,15122) ; 3$ 우 (CESC 7193, 7194, 7195); Triunfo, 1 우 (MCN 95050); Santa Cruz do Sul, 1 우, 3 주 (CESC 975, 988, 990, $5758)$.

\section{Agelaia angulata (Fabricius, 1804)}

Description. FWL 15.11-16.11 mm, mean $15.61(\mathrm{n}=4)$. Black. Antennae with scape black and flagellum ferruginous. Mandibles reddish to brownish. Body almost entirely covered with short hairs. Wings hyaline with costal region of fore wings yellowish, venation brownish.

This species was collected, for the first time, in the northwest region of Rio Grande do Sul state. It is a very widespread species, occurring from Mexico to northern Argentina.

Material examined. BRAZIL, Rio Grande do Sul: Derrubadas, 4 우 (CESC 3277, 3294, 3296, 3299).

\section{Agelaia pallipes (Olivier, 1792)}

Description. FWL 9,09-9,21 mm, mean 9,15 (n=4). Yellow with black maculation. Antennae with scape brown above, testaceous beneath; flagellum brown. Clypeus entirely yellow. Head yellow with black markings on vertex and frons. Mesoscutum black with two yellow stripes. Terga I-II yellow to testaceous/brown, terga III-VI entirely black (sometimes tergum III with a distinct yellow stripe). Legs entirely yellow. Wings hyaline with costal region of fore wings light yellowish, venation yellowish.

This species was also collected, for the first time, in the northwest region of Rio Grande do Sul state. It seems to be a species of tropical distribution, being restricted to the central and northern regions of South America. This is the first record

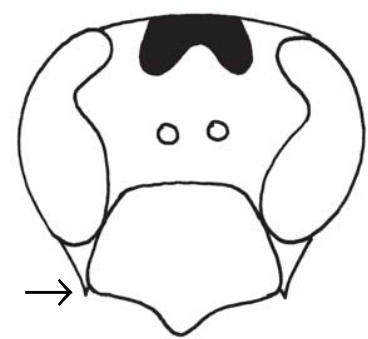

A

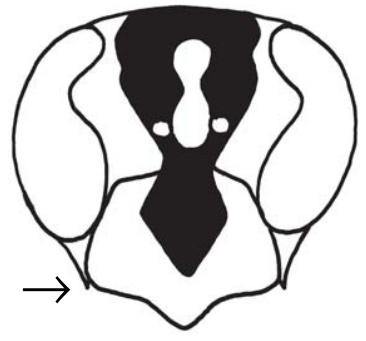

B
Fig. 3. Clypeus: A, entirely yellow; B, yellow with black markings.

from Rio Grande do Sul and from a temperate climate area. We have not seen nests of this species but, according to GARCETEBARRETT (1999) it can be found in open fields and in high forests.

Material examined. BRAZIL, Rio Grande do Sul: Derrubadas, 4 우 (CESC 3283, 3302, 3304, 3307); Tenente Portela, 1 우 (MCN 95501).

Acknowledgements. The authors would like to thank James M. Carpenter (American Museum of Natural History, New York), for his unconditional help with comments and literature; Bolivar R. GarceteBarrett and John Kochalka (Museo Nacional de Historia Natural del Paraguay, San Lorenzo), and Gabriel A. R. Melo (Universidade Federal do Paraná, Curitiba), for reading the manuscript and for their very helpful comments. Also, a very special thanks to the institutions in Rio Grande do Sul (MCNZ, MCTP) for the disposal of the material examined.

\section{REFERENCES}

Carpenter, J. M. \& O. M. Marques. 2001. Contribuição ao Estudo dos Vespídeos do Brasil. Série Publicações Digitais 3, Universidade Federal da Bahia, Departamento de Fitotecnia, CD.

Cooper, M. 2000. Five new species of Agelaia Lepeletier (Hym., Vespidae, Polistinae) with a key to members of the genus. New synonymy and notes. Entomologist Monthly Magazine 136: $177-198$.

Cooper, M. 2001.Two new species of Agelaia Lepeletier (Hym., Vespidae, Polistinae). Entomologist Monthly Magazine 137: 233-236.

Garcete-Barrett, B. R. 1999. Guía ilustrada de las avispas sociales del Paraguay (Hymenoptera: Vespidae: Polistinae). London, The Natural History Museum, 44 p.

Hunt, J. H.; S. O’Donnel; N. Chernoff \& C. Brownie. 2001. Observations on two Neotropical Swarm-Founding Wasps, Agelaia yepocapa and A. panamaensis (Hymenoptera: Vespidae). Annals of the Entomological Society of America 94(4): 555-562.

JEAnNE, R. L. 1975. The adaptiveness of social wasp nest architecture. The Quarterly Review of Biology 50: 267-287.

Richards, O. W. 1978. Social wasps of the Americas, excluding the Vespinae. London, British Museum (Natural History), 580 p.

Sakagami, S. F.; S. Laroca \& J. S. Moure. 1967. Wild bee biocenotics in São José dos Pinhais (PR), south Brazil. Preliminary report. Journal of the Faculty of Science, Hokkaido University, Ser. VI, Zoology 16: 253-291.

Silveira, O. T. \& J. M. Carpenter. 1995. A new species of Agelaia Lepeletier from Brazilian Amazonia (Hymenoptera, Vespidae: Polistinae). Journal of the New York Entomological Society 103: 69-72.

Wenzel, J. W. 1998. A generic key to the nests of hornets, yellowjackets and paper wasps worldwide (Vespidae: Vespinae, Polistinae). 
American Museum Novitates 3224: 1-39.

Zucchi, R.; S. F. SaKagami; F. B. Noll; M. R. Mechi; S. Mateus; M. V. Baio \& S. N. Sнiмa. 1995. Agelaia vicina, a swarm-founding polistine with the largest colony size among wasps and bees (Hymenoptera: Vespidae). Journal of the New York Entomological Society 103: 129-137.

Received 08.IV.2003; accepted 15.X.2003 